\title{
Elizabeth Bennet and Her Weaknesses
}

Julieta Ojeda Alba

Universidad de La Rioja

\begin{abstract}
Elizabeth Bennet, la heroína de Pride and Prejudice, ha sido considerada por la crítica y por su misma creadora Jane Austen como uno de los más aractivos personajes de la literatura inglesa de todos los tiempos. Este artículo sostiene que, paradójicamente, son precisamente sus debilidades e inconsistencias las que prestan al personaje su atractivo, convirtiéndolo en el motor de la acción.
\end{abstract}

Jane Austen created a wide gallery of interesting characters in her fiction, but according to Miss Austen herself none as delightful as Elizabeth Bennet, the heroine of Pride and Prejudice ${ }^{1}$ She wrote about her in a letter dated January 29th, 1813, "I must confess that I think her [Elizabeth] as delightful a creature as ever appeared in print, and how shall I be able to tolerate those who do not like her at least, I do not know...". ${ }^{2}$ We do agree that it would be difficult to deny her immense charm and appeal and there is a general consensus among the critics that she is "surely one of the half dozen most captivating heroines of English fiction.", ${ }^{3}$ but in spite of her many attractions there are in her a number of weaknesses and follies that would certainly have been criticised in a less compelling heroine. We must confess though that we do not begrudge these characteristics since their presence adds humanity and freshness to her personality, acting also as a foil to the dull conformity of the rest of the characters who move "in their elegant but confined houses." 4 The purpose here is to point out these weaknesses in character and call attention to their effect on the plot as they work in the particular socio-economic conditions of the beginning of the 19th century. ${ }^{5}$

In general Elizabeth is overly self-assured and rushes to conclusions about people and situations in a way that often creates problems for herself and for others. For example, when after the visit to the Philips family Elizabeth informs her sister Jane of Wickham's 
negative account of Darcy's character, the older Miss Bennet expresses her astonishment at the news exclaiming, "It is difficult indeed-it is distressing.- One does not know what to think.", to which her sister replies with a confidence that is later proved unjustified, "I beg your pardon;-one knows exactly what to think." A similar example of disproportionate self-confidence is also apparent in her dialogue with Bingley. Curiously enough such flaws in the character of our heroine are precisely the very traits that make her so enjoyable. More importantly they are also the fuel for the central plot and they initiate the feud between Elizabeth and Darcy and bring it to a successful and happy resolution.

One of her ingratiating charms which is later compromised is her categorical rejection of marriage motivated by wealth. Elizabeth absolutely refuses a union based solely on practicality, as she proves when she rejects her cousin Collins's offer and even more so when she refuses Darcy, a man worth ten thousand pounds a year. She exhibits this attitude on many occasions and she is appalled to realise that her close friend Charlotte "would have sacrificed every better feeling to worldly advantage." 7 and furthermore in conversation with Jane she describes Charlotte's search for security in marrying Collins as "unaccountable! in every view. . . unaccountable." 8 However this hasty and self-righteous judgement of Charlotte shows little consideration of circumstances in her friend's life. Elizabeth is obviously not completely aware that, as W. Smith puts it, "In Austen's society, wedlock was the expected means for single young women to gain or retain social and economic security" and that since "their chief alternatives were remaining a spinster or becoming a governess, they may have thought of little else." , as was indeed the case also in the universe of this novel.

Elizabeth's altruism ultimately comes to naught in her own case as she, fortunately enough, marries Darcy, the rich man she had previously refused. Although we do not mean to state that wealth is her primary concem, there is evidence that she was not at all indifferent to Darcy's station in life. We cannot help detecting some truth in her reply to Jane's question about her love for Darcy, "Will you tell me how long you have loved him?" Elizabeth's answer is, "I must date it from my first seeing his beautiful grounds at Pemberley." 10 Indeed Pemberley is seen in the novel as the expression of all that is good in Darcy but are we expected to believe that his ostensible wealth is not noticed by Elizabeth? Even if it be argued that she is in her usual playful manner 
speaking in jest, is there not always at least some grain of truth in jokes? Elizabeth could not have been oblivious to the economic realities of a time in which money matters were among the most important considerations in choosing a husband. Some of her later references to Darcy's estate also show that in fact she did have the wealth of Pemberley in mind.

Indeed, while on the Pemberley grounds itself, she admires its elegance and Darcy's taste and compares it positively with the excessive pretensions of Rosings as she significantly reflects, "And of this place. . . I might have been mistress! With these rooms I might now have been familiarly acquainted." 11 To evaluate Elizabeth fairly it is again extremely important to realise that in her regretful reflections she does not agonise over having rejected Darcy's qualities but rather on having rejected Darcy's wealth. While walking about the rooms in Pemberley she pointedly muses about Darcy's possessions that she believed were lost. Referring to the rooms she says, "I might have rejoiced in them as my own." 12 She is at this moment as much interested in comfort and material assets as her "insensitive" friend Charlotte ever was, and perhaps with less justification considering her younger age and better accomplishments. Let us not forget that Elizabeth is only twentyone and reputedly attractive while Charlotte is twenty-seven and she herself has admitted not "having ever been handsome". ${ }^{13}$

Miss Austen's irony is blatant. Later on when Elizabeth is already engaged to marry Darcy we are told that she is anxious to be "removed from society so little pleasing to either, to all the comfort and elegance of their family party at Pemberley," (emphasis added). ${ }^{14}$ So she certainly was looking forward to the luxury that her marriage to Darcy was to provide. Poor Charlotte had been criticised for doing just that on a lower scale but we accept Elizabeth's plans for marriage more readily than we accepted Charlotte's. One of the reasons is, of course, that we ourselves believe the sophisticated Darcy to be far more worthy of being loved by Elizabeth than we believe the pompous Mr. Collins to be deserving of any warm feelings from Charlotte. Nonetheless Elizabeth's remarks sufficiently prove that her love is mixed with a good portion of the practical, as one could expect to find in a young lady of those times.

Turning again to Charlotte, we suspect the reader, like Elizabeth, to be unjustly hard on the future Mrs. Collins. Her position is valid. Jane is right when she tells Elizabeth, after the latter has given way to her 
anger about her friend's marriage, "You do not make allowance enough for difference of situation and temper.", obviously meaning that Elizabeth is applying her life and values unfairly to Charlotte. ${ }^{15}$ That is exactly what we readers do also, partially because in many ways we see Mr. Collins through Elizabeth's eyes and she is extremely forceful when she says to her sister about him: "My dear Jane, Mr. Collins is a conceited, pompous, narrow-minded, silly man; you know he is, as well as I do." ${ }^{16}$ Elizabeth goes so far as to deny him the right to be loved, and that seems somewhat unfair, no matter how obnoxious he may be. If we allow Elizabeth the right to change her heart towards Darcy, why do we not allow Charlotte to change hers towards Mr. Collins? If we find it perfectly natural to expect that Darcy's pride should be tempered by the wit and spontaneity of the enterprising Elizabeth why can we not admit the probability of Charlotte's undeniable common sense and intelligence being a good influence in making Mr. Collins a more sensible man? After all "respectability" was very much a valued goal of young women of the lower gentry at that time and Charlotte should not be blamed for accepting what appeared to be her only chance to attain it. In her excess of self-assurance Elizabeth was much too precipitate and overly critical of her friend, and ironically, we cannot be sure that she was totally exempt from a similar charge. ${ }^{17}$

Another issue relevant to the overrating of Elizabeth's character is that of her wisdom. From the very beginning of the novel the reader is led to believe that, except perhaps for Jane, and of course Mr. Bennet, whose abilities are abundant but who won't do anything to correct the indiscretions of his wife and daughters, Elizabeth is the only sensible member of the Bennet family. ${ }^{18} \mathrm{Mr}$. Bennet himself puts us in that rain of thought when in discussing with his wife the possibilities of one of their daughters being chosen as wife of the rich newly arrived Mr. Bingley he says, "I must throw in a good word for my little Lizzy."19 As we tend at first to take Mr. Bennet's opinions at face value, Elizabeth's character is thus established as superior to her sisters'. Elizabeth is presented as a combination of quickness of perception, independence of mind, and playful vivacity, but her wisdom comes into question.

In a first encounter with the novel we all perceive the many good qualities in her. These together with a great deal of what we believe is common sense make her the established centre of intelligence in the novel. Yet upon closer inspection it cannot be denied that she acts very foolishly in many instances and this we must acknowledge and include 
in her character evaluation. Some of her overlooked foolish ways, as a matter of fact, are strongly criticised by many when seen occurring in other members of her family. For instance, there is the infatuation with the officers of Meryton which seems to fill the daily life of her two younger sisters and at times, it appears, of the whole family. The reader initially sees this as only Kitty's and Lydia's lack of sensibility but it is quite clear that Elizabeth herself is by no means free of the "epidemic". She had managed to be quite indifferent to the presence of the regiment while there was not any particular officer who interested her. However, as soon as the dashing Wickham appears, she surprisingly enough shows a curious similarity to Lydia in her obsession with the officers' movements.

At the Netherfield party, after Elizabeth realised that Wickham is absent, we are told that "she [Elizabeth] had no longer any interest of her own to pursue." 20 The characters of her younger sisters Lydia and Kitty are consistently developed as frivolous and flirtatious and this opinion we hold of them is mainly based on the fact that they were extremely attracted to the officers in Meryton. How then can we fail to indict Elizabeth for the same performance? If the social conditions are such that the two younger Misses Bennet are to be blamed, so then should Elizabeth.

It is quite true that she first objected to the blatant pursuit of the officers which her sisters carried on; however, the fact is that she did not fall very short of responding to the officers in the same manner after her interest was awakened. From the moment Wickham appeared Elizabeth was as happy as Lydia and Kitty and as ready as they were to talk to the handsome young men in the middle of the street. We are told for instance that "the whole party were still standing and talking together very agreeably." 21 The whole party includes Elizabeth as well as Lydia and Kitty. Obviously her sensibility did not stop her on this occasion from doing what, at the time, was verging on impropriety. ${ }^{22}$ From our point of view Jane Austen clearly intends to accent Elizabeth's lack of delicacy by openly exhibiting her awareness of her sisters'.

Moreover, the next time Elizabeth sees Wickham she can hardly conceal her admiration, and after permitting him to do a good deal of gossiping against Darcy she is captivated enough by Wickham to thoughtlessly declare that "he [Darcy] deserves to be publicly disgraced." 23 This declaration is based on some unlikely story about the 
latter which Elizabeth was gullible enough to believe. This statement was at best too hasty and at worst a major folly. She evidently did not reflect on the fact that this was only the second time she had ever talked to Wickham who was a newcomer and thus she had not enough data to trust his words, especially when they were destroying the character of a respectable, if not agreeable, human being whose only conspicuous fault is aloofness.

We can look to Elizabeth's acclaimed verbal acumen also to find another example of her distinct human weakness. ${ }^{24}$ Elizabeth has a strong tendency to exhibit her quick wit at some expense to her companions, and on several occasions on she answers a compliment with a criticism, as when Charlotte is eager to give Elizabeth an opportunity to demonswate her musical accomplishment and the latter answers in a slightly contemptuous manner: "You are a very strange creature by way of a friend! always wanting me to play and sing before anybody and everybody!" 25 Such a manner of reply can often compromise the supposed intentions of the friend who, at least in this case, is quite innocent. Later on, when Charlotte comes to tell her friend about her new engagement to Collins, Elizabeth's startling reaction, according to the author's own words, overcomes "the bounds of decorum" when she says: "Engaged to Mr. Collins! My dear Charlotte,impossible!" 26 This exclamation of Elizabeth's certainly deserves Charlotte's following accusation that clearly her friend presumed that because she herself did not accept Mr. Collins, nobody else would.

Elizabeth can be insolent, although it is difficult for a late twentieth century reader to be aware of the extent of her sauciness and her affronts; her language was surely far more offensive at the beginning of the nineteenth century than now. Mary Russell Mitford wrote in a letter to William Elford in December, 1814, "It is impossible not to feel in every line of Pride and Prejudice in every word of Elizabeth, the entire want of taste which could produce so pert, so worldly a heroine as the beloved of such a man as Darcy." ${ }^{27}$ Evidently there have been people who have disagreed with the author in their opinion of Elizabeth Bennet's charms and glamour.

Elizabeth clearly overvalued her wit and intelligence for she later confesses having sometimes injudiciously praised herself for these qualities. She admits her error in the dramatic scene when she humbles herself after reading Darcy's letter and cries, 
How despicably have I acted! . . I who have prided myself in my discernment!- I, who have valued myself on my abilities! Who have often disdained the generous candour of my sister, and gratified my vanity, in useless or blameable distrust. . . . Had I been in love, I could not had been more wretchedly blind. But vanity, not love, has been my folly. ${ }^{28}$

Elizabeth's vanity is by no means her only folly. The mere frequency of her blunders makes us question her supposed keenness. It is true, we must admit, that Elizabeth's opinions of people are in some cases proved to be correct. She was very capable of evaluating Mr. Collins, identifying from the start his conceit, his lack of understanding, and his pomposity. She was also able to see through the affected sweetness of the Bingley ladies towards her sister, while Jane herself was completely fooled. ${ }^{29}$ Nevertheless, Elizabeth did not consistently show the same high quality of judgement towards all people and circumstances, and there are several important examples of her continued oversights which can be easily identified.

She is often unable to understand certain situations that occur within the story line. For instance, while staying at Rosings she often happened to encounter Darcy on her rambles within the park and "to prevent its ever happening again took care to inform him at first that it was a favourite haunt of hers." 30 Her naive expectation was that it would never occur again and she was astonished when it did a second and even a third time. Any person with the minimum of common sense would understand that they clearly were not chance encounters and that Darcy was seeking them. However, the reputedly "clever" Elizabeth failed to see what would have been obvious to just about anyone else and which is plain to the reader.

One of her greatest failures of perception is her long standing expectations for Charlotte. Her marriage to Mr. Collins took Elizabeth completely by surprise and she was embittered and mortified by it as previously discussed. Nevertheless, it is plain that she had many reasons to be prepared for it well in advance yet she was not in the least. Charlotte herself had given Elizabeth sufficient hints for her to believe that it was very much in her [Charlotte's] character to accept a marriage such as Mr. Collins could offer. She had already made some comments that would have been a clear indication for anyone paying attention. As early as chapter six when discussing with Elizabeth the possibility of an 
attachment between Jane and Bingley, Charlotte states that Jane should make more effort in that direction and then she adds, "When she is secure of him there will be leisure for falling in love as much as she chuses [sic]." ${ }^{31}$ Elizabeth then understands the implications of such an opinion, as it is evident from her reply, but she fails to see that Charlotte is speaking from the heart, and that her expressed views would dictate, given the opportunity, her own behaviour. She later confirms what we already knew, and Elizabeth should have known if she had behaved in accordance with our expectations. After disclosing to Elizabeth her engagement to Mr. Collins, Charlotte gives her reasons for accepting him: "I am not romantic you know. I never was. I ask only a comfortable home." 32 Miss Lucas, as MacDonagh puts it, "has lived up to her creed." 33 She is evidently neither idealistic nor romantic, but she is altogether coherent and she has a good understanding of what her options are. She simply recognises that this may well be her only offer, the last one. Who can blame her for being prepared to endure Mr. Collins as a better option than being a spinster living on the charity of one of her siblings for the rest of her life? Evidently Elizabeth does, but it remains to be decided if she is being fair to her friend.

Elizabeth's stated evaluation of Charlotte's parents also appears to be in conflict with the evidence and thus inaccurate. It seems to us that she should have long been aware of the limitations of Sir Lucas. He had recently been elevated to knighthood and shows that he does not yet carry the title with grace. His social abilities are far from perfect. To confirm this we have the account of the visit to Rosings when Sir Lucas is presented almost as a double of Mr. Collins. The reader, if not Elizabeth, is by that time already aware of the knight's faulty and awkward manners since he had put both Darcy and Elizabeth on the spot by his earlier attempt to interest Darcy in dancing. On that occasion even Charlotte had apologised for her father's interventions. Yet in spite of all this Elizabeth is able to say to Charlotte in reference to her parents' social value, "You are very lucky in parents", which must necessarily mean that she is either making an attempt to flatter Charlotte, or more probably that she has again been unable to justly evaluate some of her acquaintances. ${ }^{34}$ None of these interpretations leave Elizabeth in a graceful position.

In terms of plot development Elizabeth made one of her most meaningful and influential mistakes by putting faith in Wickham's 
words. She misjudges him for several reasons: she finds him very attractive and amiable, she is being flattered by him, and he openly criticises Darcy, the very man she dislikes most, significantly because he wounded her pride. Nevertheless it is only fair to say that she is not totally to blame in the matter of her infatuation with Wickham for he is an expert in fooling people. He was, in fact, adroit enough to deceive the whole town; "He [Wickham] is universally liked," says an officer, and many others share a similar opinion, a general error that is exposed when he finally elopes with Lydia. ${ }^{35}$ Both the reader and the heroine receive sufficient clues of Wickham's impropriety but the latter could not or would not discern them. Wickham cautiously tests Elizabeth before he starts destroying Darcy's character, "Are you much acquainted with Mr. Darcy?" he asked. Elizabeth immediately responds, "As much as I ever wish to be", and she adds, "I think him very disagreeable." 36 This disapproving remark opens the way to Wickham's crude and slanderous criticism while Elizabeth remains unaware of the impropriety of Wickham's speech delivered on only their second meeting. Elizabeth listened with complacency and permitted Wickham, practically a stranger, to slander Darcy whom, however haughty Elizabeth might have considered him to be, she did not have any reason to believe to be evil.

Nevertheless our heroine was unable to interpret the magnitude of what her new. acquaintance was doing. If anyone else in her circle had acted as Wickham had she would probably have been incensed, but he was too good-looking for her to see with a critical eye. After this particular interview the narrator comments, "Elizabeth went away with her head full of him. She could think of nothing but of Mr. Wickham." 37 Her own vanity, as she herself admits, caused her perception to be eclipsed in this case also. Elizabeth liked attention and because she got it from Wickham, she was prepared to believe and admire any speech that this handsome man who intentionally flattered her would deliver. Why, if not, would she be so blind as to ignore the inadequacy of his bold remarks about Darcy?

Elizabeth's is not a momentary folly. She persists long in this mistake. When she is told that Wickham is "courting" a not very attractive girl who had just inherited some money, instead of reacting as she had done in the case of her friend Charlotte, she excuses him. We do not know if she did it in order to deny a potential jealousy or just because she liked him so much that nothing he did could make any difference, but 
it is certainly inconsistent in any case. She finally reacts and sees Wickham as he really is, but only after Darcy has written her a letter explaining, among other things, Wickham's dishonourable behaviour and his attempt to elope with his [Darcy's] sister. She herself finally realises her fault and says she ". . . was now struck with the impropriety of such communications to a stranger, and wondered it had escaped her before." 38

Elizabeth is at last aware of Wickham's real character and the extent of her mistake and begins to analyse and chastise herself too: "She grew absolutely ashamed of herself.-Of neither Darcy nor Wickham could she think, without feeling that she had been blind, partial, prejudiced, absurd." 39 Nevertheless this admission of her guilt does not mean that she is forever cured of foolishness since, after all, the modification of her criteria is once again based on insufficient evidence, in this case merely a letter. It rather ascertains that together with the lovely characteristics of her personality there are other, less desirable, even damaging traits in her character. As Weinsheimer puts it, ". . . the scope of her understanding is too small, that it has gathered too little data to evaluate circumstances accurately." 40

Elizabeth's misjudgement of Darcy is, of course, central to the plot and, interestingly, it has some sources opposite to those leading to her misjudgement of Wickham. Darcy had slighted Elizabeth within her hearing at the first dance that they both attended and although she, as corresponds to her proud character, assumes indifference and goes out to tell all her friends about it, we know that she did not take it so lightly. It decisively affected her opinion of him. When Darcy and his pride are being discussed in chapter five Charlotte says she can excuse pride in a man like Darcy who "has a right to be proud", on account of his family and fortune, etc. Elizabeth acknowledges it and answers, "That is very true, and I could easily forgive his pride, if he had not mortified mine." 41 Thus her antagonism toward Darcy has its true origin in a chance remark and her own egocentric vanity, and it is this particular manifestation of this fault of "delightful" Elizabeth that turns out to be the driving force of the entire story. ${ }^{42}$

It is worth pondering at this point that if Darcy had not slighted her at the first ball and had she not been snubbed and supposedly devoid of opportunities to conquer him, she might have acted much more in the subservient way of Miss Bingley, consequently destroying what was the 
main attraction in her for Darcy. We know that he is tired of women who would agree with him just to ingratiate themselves and that it is only the challenge of touching Elizabeth's heart and mind that is the immediate focus of his interest in her. Elizabeth becomes at the end well aware of this when she tells him: "The fact is, that you were sick of civility, of deference, of officious attention. You were disgusted with the women who were always speaking and looking, and thinking for your approbation alone. I roused and interested you because I was so unlike them." 43 True enough! So we must give thanks to one of the aforementioned "weaknesses" in her character, that the plot so early on has a situation strongly in need of resolution.

A close reading of the novel shows that Jane Austen skilfully shapes Elizabeth's personality and her judgement of others to demonstrate that in fiction, as in real life, the truth is elusive. In Pride and Prejudice the characters are not what they seem at first to be and, in fact, we are often reminded of our not being in full possession of the elusive truth about each. We labelled Mrs. Bennet silly and inadequate because of her frantic pursuit of husbands for her daughters, but given the range of expectations of early nineteenth century young maidens her attitude is absolutely legitimate. We see Mr. Bennet as a model of intelligence and propriety but we soon realise that he is a model only of an inept father and husband. ${ }^{44}$ Wickham is also at first, especially in the eyes of Elizabeth, an archetype of amiability and good manners but is soon discovered to be a scoundrel, while Darcy, universally disliked for his excessive pride, and even suspected of villainy, turns out to be an indisputable paradigm of "amiability".

This ambiguity of the characters also reaches Elizabeth who, in fact, is the most elusive to define. She is after all delightful, we do not deny the true delight that so many readers and critics have noticed and written about, but her inconsistencies and weaknesses are deeper and more abundant than meet the eye at first. The qualities of wit and liveliness that give her such universal appeal overshadow these blemishes in her character. She is presented as possessing uncommon independence but even this paramount quality is ultimately questionable, since at the end she seems amenable even to being tamed by Darcy and accepting a subordinate role. Her resistance to participate in the husband hunting ritual common, and indeed unavoidable given the limited range of possibilities open for women, slowly erodes in the 
presence of the eligible Mr. Darcy. ${ }^{45}$ Her indifference to wealth is at least questionable, as demonstrated. Her wisdom is rendered ineffectual not only by the sexual appeal of Wickham, but also by Darcy's former flippant indifference to her beauty. Her manners, especially toward Darcy and Lady De Bourgh, are frequently bordering on impropriety if not actually improper.

It seems that Jane Austen wanted to demonstrate the elusiveness of truth through the whole novel and mainly through her main character. Elizabeth's improprieties work in her favour as far as Darcy is concerned and we detect the beginning of his interest precisely on the occasion of her "improper" walk from Longbourn to Netherfield. Darcy "was divided between admiration of the brilliancy which exercise had given to her complexion, and doubt as to the occasion's justifying her coming so far alone." 46 This clearly suggests that Darcy cannot fully decide whether to praise Elizabeth's brilliant spontaneity and sprightliness or to rebuke her for her "unjustified" show of independence. His growing admiration ultimately gets the upper hand, and the continuing effects of her other errors form much of the plot and cooperate in bringing together the discordant pair. It is then fair to say that her charm, her delight, her success as a character and with Darcy are largely founded upon that vanity and overconfidence that, certainly not virtues, do favourably single her out from the crowd of security seeking young ladies. Yet no matter how much they contribute to Elizabeth's success they must be given full due as the imperfections that they are.

All of these imperfections are intelligently and intentionally guided and controlled by the author in order to establish her beliefs. Jane Austen recognised the multiplicity of meanings that human actions are susceptible of having and she implemented this knowledge in her novels. Pride and Prejudice is a magnificent example of her achievements. Within this novel there are several other characters who demonstrate the same penchant, but our heroine is certainly one of the most outstanding examples; one who moreover is used in a twofold way since through her eyes we are also allowed to see other characters' ambiguities. 


\section{NOTES}

1. Although Pride and Prejudice was published in 1813 Jane Austen began the work in 1796 and she then titled it First Impressions.

2. Malden, S. F. Jane Austen, p. 75.

3. Harry Blamires. A Short History of English Literature, p. 314.

LeRoy W. Smith also calls Elizabeth "the most captivating of Austen's valiant women" Jane Austen and the Drama of Women. New York: St. Martin's Press 1983) 90.

4. From a letter written by Charlotte Brontë to G. H. Lewes in which the former mildly criticises Pride and Prejudice.

5. R. W. Chapman observes that it is possible to demonstrate Jane Austen's correlation of Pride and Prejudice to the calendar of 1811 and 1812 , though he adds that we are free to suppose that she conceived the events as belonging to the last decade of the eighteenth century.

6. Jane Austen, Pride and Prejudice, p. 129.

7. Austen, p. 166.

8. Austen, p. 174.

9. LeRoy W. Smith, p. 87.

10. Austen, p. 382.

11. Austen, p. 268.

12. Austen, p. 269.

13. Austen, p. 163.

14. Austen, p. 392.

15. Austen, p. 174.

16. Austen, p. 174.

17. Oliver MacDonagh calls attention to the similarity between Charlotte's decision and Miss Austen's. It is clear that at least in Pride and Prejudice. the author preferred marriages of love to pragmatic marriages but she was also in a position to understand the motivations for the latter. In December 1802 Jane accepted a sudden offer of marriage from Harris Bigg Wither, the son of the Biggs at whose home Jane and her sister Cassandra had arrived a week earlier for a visit. Harris was six years Jane's junior and it seems that had the marriage taken place its purpose would have been mainly for Jane to avoid spinsterhood but she broke off her engagement the next day. See Oliver MacDonagh's Jane Austen: Real and Imagined Worlds.

18. Mr. Bennet, married to an empty woman whose sexuality and youth had been the main attractions for him, is quite cynical about his role as a husband and a father.

19. Austen, p. 52 . 
20. Austen, p. 140.

21. Austen, p. 116.

22. Miss Bingley uses the Misses Bennet's admiration of the officers to devaluate Elizabeth in front of Darcy.

23. Austen, p. 123.

24. Alice Chandler in "A pair of fine eyes" calls Elizabeth "the most articulate of Jane Austen's protagonists", p. 33.

25. Austen, p. 71.

26. Austen, p. 165.

27. Letter from Mary Russell Mitford to Sir William Elford, December, 20, 1814 in B. C. Southam, (ed.). Jane Austen: Sense and Sensibility, Pride and Prejudice, and Mansfield Park: a Casebook, p. 153.

28. Austen, p. 236.

29. It is important to mention that for a while Elizabeth was also fooled by the Bingley sisters. During Jane's illness the narrator observes that "Elizabeth began to like them [the Bingley sisters] herself, when she saw how much affection and solicitude they showed for Jane." Austen, p. 79.

30. Austen, p. 215.

31. Austen, p. 69.

32. Austen, p. 165.

33. MacDonagh, p. 34.

34. Austen, p. 67

35. Austen, p. 133.

36. Austen, p. 121.

37. Austen, p. 127.

38. Austen, p. 235.

39. Austen, p. 236.

40. See Joel Weinsheimer, "Chance and the Hierarchy of Marriage in Pride andPrejudice" in Harold Bloom ed. Jane Austen: Modern Critical Views.

41. Austen, p. 67.

42. An interesting discussion on the influence of chance on marriages in Jane Austen's fiction is found in Joel Weinsheimer's above mentioned article "Chance and the Hierarchy of Marriages in Pride and Prejudice".

43. Austen, p. 388.

44. Mr. Bennet, like most fathers in Jane Austen's fiction, is ineffective. He is unable to check the follies of his wife and daughters since he never takes direct responsibility for his family.

45. Elizabeth at one time wonders whether she should try to use her power over Darcy to bring on the renewal of his addresses which in fact approximates her behaviour to Miss Bingley's.

46. Austen, p. 79. 


\section{BIBLIOGRAPHY}

Austen, Jane. 1988 (1813). Pride and Prejudice. London: Penguin Books.

Blamires, Harry. A Short History of English Literature. London: Methuen \& Company Ltd.

Bloom, Harold. 1994. The Western Canon. The Books and Schools of the Ages. New York: Harcourt Brace \& Company.

Bloom, Harold. ed. 1986. Jane Austen: Modern Critical Views. New York and Philadelphia: Chelsea House Publishers, p. 13-46.

Chandler, Alice. 1975. "A pair of fine eyes", in Studies in the Novel. 7:1.

Fergus, Jan. 1992. Jane Austen: A Literary Life. Houndmills: Macmillan Press.

Gard, Roger. 1992. Jane Austen's Novels: The Art of Clarity. New Haven: Yale University Press.

Handler, Richard \& Daniel Alan Segal 1990. Jane Austen and the Fiction of Culture: An Essay on the Narration of Social Realities. Tucson: University of Arizona Press.

Hardy, John P. 1985. Jane Austen's Heroines: Intimacy in Human Relationships. London: Routledge \& Kegan.

Le Faye, Deidre, ed. 1995. Jane Austen's Letters. Oxford and London: Oxford University Press.

MacDonagh, Oliver. 1991. Jane Austen: Real and Imagined Worlds. New Haven and London: Yale University Press.

Malden, S. F. (Mrs. Charles Malden). 1889. Jane Austen. London: W. H. Allen \& Company.

Morgan, Susan. 1980 In the Meantime: Character and Perception in Jane. Austen's Fiction. Chicago: University of Chicago Press.

Scheuermann, Mona. 1993. Her Bread to Earn: Women, money, and Society from Defoe to Austen. Lexington: University Press of Kentucky.

Smith, LeRoy W. 1983. Jane Austen and the Drama of Woman. London: Macmillan.

Southam, B. C. ed. 1976. Jane Austen: Sense and Sensibility, Pride and Prejudice, and Mansfield Park: a Casebook. London: MacMillan Publishers.

Wallace, Tara Ghoshal. 1995. Jane Austen and Narrative Authority. London: Macmillan Publishers. 